\title{
Pengaruh Jumlah Tanaman Per Lubang Terhadap Vigor Benih Tiga Varietas Sorgum (Sorghum bicolor [L].Moench) Dengan Metode Pengusangan Cepat (MPC)
}

\section{Effect of Amount Per Hole Against Plant Seed Vigor Three Varieties Sorghum (Sorghum bicolor [L].Moench) with Metode Pengusangan Cepat (MPC)}

\author{
Lidya Purnamasari ${ }^{1}$, Eko Pramono ${ }^{2}$, dan M. Kamal ${ }^{2}$ \\ ${ }^{1)}$ Mahasiswa Jurusan Agroteknologi, Fakultas Pertanian Universitas Lampung \\ ${ }^{2)}$ Dosen Jurusan Agroteknologi, Fakultas Pertanian Universitas Lampung \\ Jln Prof. Soemantri Brodjonegoro, No.1, Bandar Lampung
}

\begin{abstract}
The aim of this study is to determine the effect of the number of plants per hole on seed vigor of all sorghum varieties. Experiment is prepared by treatment with randomized block design (RAK) and repeated three times to do to achieve that goal. The first factor is the number of plants per hole that is 1 plant / hole (p1), 2 plants / hole (p2), 3 plants / holes (p3), and 4 plants / hole (p4). The second factor is the variety Numbu (g1), Keller (g2), and Wray (g3). The seed that had been harvested from each of the combination treatments in the test vigornya through germination test method Rolled Paper Test (UKD). Prior to germinate, seeds treated quickly with imbibition pengusangan on rice paper damp ethanol $8 \%$. The results showed that the population of one plant per hole produces seeds with higher vigor than those harvested from other populations. Numbu varieties produce seeds with higher vigor than varieties Keller and Wray especially on untreated seed pengusangan quickly. Population 1 plant per hole produces the best vigor compared with a population of 2, 3 and 4 plants per hole on the three varieties of sorghum seed.
\end{abstract}

Keywords: seeds, planting amount per hole, metode pemngusangan cepat, sorghum, vigor

Diterima: 10-11-2014 disetujui 07-02-2015

\section{PENDAHULUAN}

Pangan merupakan kebutuhan utama manusia. BPS (2010) melaporkan bahwa laju pertumbuhan penduduk Indonesia setiap tahunnya meningkat 1,48 \% sejak tahun 2000. Dengan bertambahnya jumlah penduduk Indonesia setiap tahunnya menyebabkan kebutuhan akan pangan juga semakin meningkat. Usaha peningkatan produksi pangan terus dilakukan dan salah satu upaya pemerintah dalam mengatasi masalah pangan adalah dengan diversifikasi pangan. 
Lidya Purnamasari dkk: Pengaruh Jumlah Tanaman Per Lubang Terhadap Vigor Benih Tiga Varietas Sorgum...

Berkaitan dengan program diversifikasi pangan di Indonesia, sorgum merupakan serealia yang potensial untuk digunakan sebagai substitusi beras karena kandungan gizinya setara (Sirrapa, 2003). Namun demikian di Indonesia, sorgum (Sorghum bicolor [L.] Moench) merupakan salah satu jenis tanaman pangan yang pengembangannya tidak sebaik tanaman pangan lainnya seperti padi dan jagung. Padahal tanaman ini memiliki potensi yang baik untuk dikembangkan secara komersial di Indonesia. Hal ini disebabkan oleh kondisi agroekologis yang mendukung serta ketersediaan lahan yang cukup luas.

Salah satu cara peningkatan produktivitas sorgum dapat ditempuh melalui rekayasa teknologi produksi, yaitu dengan pengaturan kerapatan tanam. Produksi yang optimal dapat diperoleh dengan menentukan kerapatan tanam yang optimal. Pengaturan kerapatan tanam dilakukan dengan cara menanam dengan jarak tanam yang berbeda dan melalui manipulasi jumlah benih per lubang dengan jarak tanam tetap. Penentuan kerapatan tanam yang tepat umumnya bertujuan untuk meningkatkan produksi sorgum. Sebetulnya, kerapatan yang tepat juga bisa mendapatkan benih yang bermutu karena produksi benih berlangsung pada tingkat kompetisi antar tanaman yang rendah.

Benih merupakan salah satu faktor yang menentukan hasil suatu tanaman, sehingga benih memiliki peranan yang sangat penting dalam proses produksi tanaman. Benih bermutu merupakan sebuah konsep yang kompleks yang mencakup sejumlah faktor yang masing-masing mewakili prinsipprinsip fisiologi, seperti daya berkecambah, viabilitas, vigor dan daya simpan. Mutu benih terdiri dari mutu fisik, fisiologi dan genetik (Sadjad, 1993).

Salah satu faktor yang mempengaruhi perbedaan vigor dan viabilitas benih adalah kondisi lingkungan selama perkembangan benih di lapangan. Faktor-faktor yang mencakup lingkungan tersebut antara lain ketersediaan unsur hara, cahaya, suhu dan air. Perbedaan kerapatan tanam secara langsung akan menyebabkan persaingan tanaman dalam menggunakan faktor lingkungan yang ada tersebut. Hal ini juga akan mempengaruhi mutu benih yang akan dihasilkan oleh tanaman induk. Selain faktor lingkungan, faktor genetik juga mempengaruhi perbedaan mutu benih. Kemampuan menyerap unsur hara dari setiap varietas berbeda-beda. Hal ini dapat terjadi karena sifat genetik dari setiap varietas berbeda sehingga dapat membedakan mutu dari setiap benih.

Metode pengusangan cepat kimiawi dengan etanol merupakan salah satu cara yang dapat mengungkapkan daya simpan dugaan dari suatu lot benih. Dengan metode pengusangan ini, benih diperlakukan dengan larutan etanol dengan konsentrasi yang berbeda sehingga benih akan mengalami kemunduran mutu dengan cepat seperti halnya kemunduran mutu benih oleh periode waktu alamiah yang relative lama.

Tujuan penelitian ini adalah untuk mengetahui pengaruh jumlah tanaman per lubang pada vigor benih dari tiga varietas sorgum.

\section{METODE}

Penelitian dilaksanakan di Kebun Percobaan Balai Pengkajian Teknologi Pertanian (BPTP) Desa Negara Ratu, Kecamatan Natar Kabupaten Lampung Selatan dan Laboratorium Benih dan Pemuliaan Tanaman, Fakultas Pertanian, Universitas Lampung pada bulan Mei sampai November 2013.Bahan yang digunakan meliputi benih sorgum dari varietas Numbu, varietas Keller dan varietas Wray,yang dipanen pada tanggal 21 September 2013. Alat-alat yang digunakan dalam penelitian ini terdiri dari alat pengolah tanah, golok, sabit, carter, ember, gayung, alat penyedot air, selang, label sampel, gunting, millimeter blok, germinator, mistar, gelas ukur,karet gelang, timbangan elektrik, 
moisture tester, oven, dan alat tulis. Vigor benih diuji dengan metode pengusangan cepat (MPC). Bahan dan peralatan pengujian vigor meliputi larutan etanol 70\%, akuades, kertas merang, plastik, dan alat pengecambahan benih.

Penelitian ini menggunakan rancangan faktorial (4x3) dalam Rancangan Acak Kelompok (RAK) yang terdiri dari dua faktor perlakuan. Faktor pertama adalah jumlah tanaman per lubang dan faktor kedua adalah varietas tanaman sorgum. Kerapatan tanam dibagi menjadi empat taraf, yaitu satu, dua, tiga, dan empat tanaman/ lubang tanam. Varietas yang digunakan ada tiga, yaitu Numbu, Keller, dan Wray. Kombinasi perlakuan berjumlah 12 dan diulang 3 kali , kelompok sebagai ulangan, sehingga terdapat 36 satuan percobaan. Tiap satu satuan percobaan menggunakan lahan seluas 16 $\mathrm{m}^{2}$. Homogenitas ragam antarperlakuan diuji dengan uji Bartlet dan aditivitas data di uji dengan uji Tukey. Bila kedua asumsi ini terpenuhi, dilanjutkan dengan analisis ragam. Perbedaan nilai tengah antarperlakuan diuji dengan uji Beda Nyata Terkecil (BNT) pada taraf g $1 \%$.

Penanaman dilakukan dipetak-petak dengan ukuran 4m x 4m . Penanaman dilakukan setelah dilakukan pembuatan lubang tanam dengan cara ditugal dengan jarak tanam $80 \mathrm{~cm}$ x $20 \mathrm{~cm}$. Jumlah benih yang ditanam yaitu sesuai dengan perlakuan yaitu 1, 2, 3, dan 4 tanaman per lubang. Pemeliharaan dilakukan untuk menjaga tanaman tetap kecukupan air, terhindar dari serangan hama dan penyakit.

Benih yang telah dipanen, dirontokkan, dijemur di bawah sinar matahari lalu dibersihkan dari kontaminansi. Setelah kering pada kadar air kira-kira 12\%, benih di kemas dengan kantong plastik, lalu dilakukan pengenceran pada larutan etanol $70 \%$ sesuai dengan konsentrasi yang sudah ditetapkan yaitu $8 \%$. Penderaan benih dilakukan dengan cara mengimbibisikan benih dengan larutan etanol yaitu dengan meletakan benih pada gulungan kertas merang lembab etanol selama 24 jam. Benih sorgum yang telah didera dengan larutan etanol dikecambahkan pada kertas merang lembab air. Peubah pengamaatan pada percobaan ini adalah Uji Kecepatan Perkecambahan (UKP) yang terdiri dari Kecepatan Perkecambahan (KP), Kecambah Normal Total (KNT), dan Benih Mati (BM). Uji Keserempakan Perkecambahan (UKsP) yang terdiri dari Kecambah Normal Kuat (KNK), Kecambah Normal Lemah (KNL), Panjang Hipokotil (PH), Panjang Akar Primer (PAP) dan Panjang Kecambah Normal (PKN). Pengamatan dilakukan 2, 3, 4, 5,6 dan 7 Hari setelah tanam (HST) untuk UKP dan 6 HST untuk UKsP.

\section{HASIL DAN PEMBAHASAN}

Hasil ringkasan analisis ragam menunjukan bahwa pengaruh interaksi varietas dan jumlah tanam per lubang pada vigor benih ditunjukan pada benih sorgum yang sudah mendapat perlakuan pengusangan cepat dengan imbibisi pada larutan etanol konsentrasi 8\% selama 24 jam. Pada pengusangan cepat dengan menggunakan etanol $8 \%$, menunjukan adanya pengaruh yang nyata pada benih mati, kecambah normal kuat, kecambah norml lemah, panjang tajuk, panjang akar primer dan panjang kecambah normal. Kemudian perlakuan jumlah tanam per lubang juga menunjukan adanya pengaruh nyata pada beberapa variabel pengamatan yaitu kecepatan perkecambahan, kecambah normal total, benih mati dan panjang kecambah normal. Pada pengusangan cepat etanol $8 \%$ menunjukan adanya pengaruh interaksi antara varietas dengan jumlah tanam per lubang yaitu ditunjukan pada variabel pengamatan kecepatan perkecambahan, kecambah normal total, benih mati, kecambah normal lemah dan panjang kecambah normal. 
Lidya Purnamasari dkk: Pengaruh Jumlah Tanaman Per Lubang Terhadap Vigor Benih Tiga Varietas Sorgum...

Selanjutnya, hasil penelitian menunjukan bahwa pengaruh perlakuan jumlah tanam per lubang (populasi) nyata mempengaruhi mutu benih pada pengusangan cepat dengan etanol $8 \%$. Faktor populasi berpengaruh nyata dan hasil terbaik diperoleh pada populasi 1 tanaman /lubang sedangkan hasil terendah diperoleh pada populasi 4 tanaman/lubang. Hal ini diduga karena populasi tanaman yang tinggi menyebabkan persaingan dalam satu rumpun tanaman dalam memperoleh cahaya sehingga tanaman kekurangan cahaya selama masa tumbuhnya dilapangan. Rambitan (2004) dalam Usman Made (2010) mengatakan bahwa pengaturan populasi tanaman merupakan pengaturan ruang hidup tanaman sehingga persaingan dalam penggunaan unsur hara, air, dan cahaya diantara tanaman dapat ditekan sekecil-kecilnya.

Pengaruh populasi yang sangat jelas terjadi dilapangan yaitu ukuran benih yang bervariasi antar satu varietas. Ukuran terkecil ditunjukan pada sorgum yang ditanam pada populasi 4 tanaman/lubang. Populasi tanaman yang tinggi mengakibatkan penurunan bobot tanaman baik batang maupun biji yang dihasilkan. Bahkan pada populasi tanaman yang lebih tinggi rentan terhadap serangan jamur seperti yang terlihat dilapangan pada saat pemanenan hal ini sejalan dengan pendapat Koswara (1986) dalam Usman Made (2010) yang menyatakan bahwa tingkat populasi yang tinggi menimbulkan kerugian berupa batang yang lemah dan kecil, merangsang pertumbuhan jamur dan kesulitan dalam panen.

Kemudian hasil penelitian yang dilakukan menunjukan bahwa Interaksi terlihat pada pengusangan cepat dengan menggunakan etanol $8 \%$, cadangan makanan didalam setiap benih sudah mulai menurun karena kandungan etanol yang masuk kedalam benih semakin meningkat sehingga menyebabkan benih mendenaturasi protein membrane yang menyebabkan peningkatan permeabilitas kulit benih.

Dari hasil penelitian yang diperoleh dari tabel interaksi (Tabel 4, 5 dan 6) menunjukan bahwa tanaman sorgum varietas Numbu dapat ditanam sampai populasi 3 tanaman per lubang karena hasil penelitian menunjukan tidak adanya perbedaan nyata vigor benih antara populasi 1, 2, dan 3 tanaman per lubang. perbedaan terlihat pada populasi 4 tanaman per lubang dengan hasil terendah baik pada variabel kecepatan perkecambahan, kecambah normal total, dan benih mati. Pada benih sorgum varietas Keller dan Wray, hasil penelitian menunjukan bahwa varietas ini dapat ditanam pada populasi 1, 2, 3, dan 4 tanaman per lubang. Hal ini menunjukan bahwa varietas Keller dan Wray lebih tahan ketika ditanam pada populasi 4 tanaman dibandingkan Numbu.

Tabel 4. Interaksi varietas dan populasi pada variabel pengamatan kecepatan perkecambahan benih yang diusangkan cepat dengan etanol $8 \%$

\begin{tabular}{lcccc}
\hline \multirow{2}{*}{ Varietas Sorgum } & \multicolumn{4}{c}{ Jumlah tanam per lubang } \\
\cline { 2 - 4 } & 1 & 2 & 3 & 4 \\
\hline Numbu & $39,69 \mathrm{a}$ & $41,69 \mathrm{a}$ & $41,30 \mathrm{a}$ & $34,13 \mathrm{~b}$ \\
\multirow{2}{*}{ Keller } & $\mathrm{A}$ & $\mathrm{A}$ & $\mathrm{A}$ & $\mathrm{B}$ \\
& $40,85 \mathrm{a}$ & $34,51 \mathrm{~b}$ & $39,38 \mathrm{a}$ & $36,88 \mathrm{ab}$ \\
Wray & $\mathrm{A}$ & $\mathrm{B}$ & $\mathrm{A}$ & $\mathrm{AB}$ \\
& $40,37 \mathrm{a}$ & $39,77 \mathrm{a}$ & $41,41 \mathrm{a}$ & $38,49 \mathrm{a}$ \\
\hline Nilai BNT 0,01 & $\mathrm{~A}$ & $\mathrm{~A}$ & $\mathrm{~A}$ & $\mathrm{~A}$ \\
\hline
\end{tabular}

Keterangan : $\mathrm{G}=$ varietas, $\mathrm{P}=$ populasi. Dua nilai tengah yang diikuti dengan huruf yang sama tidak berbeda nyata berdasarkan uji BNT pada g 0,01. Huruf kecil untuk perbandingan dalam baris dan huruf besar untuk perbandingan dalam kolom. 
Jurnal Penelitian Pertanian Terapan

Tabel 5. Interaksi varietas dan populasi pada variabel pengamatan kecambah normal total yang diusangkan cepat dengan etanol $8 \%$

\begin{tabular}{|c|c|c|c|c|}
\hline \multirow{2}{*}{ Varietas Sorgum } & \multicolumn{4}{|c|}{ Jumlah tanam per lubang } \\
\hline & 1 & 2 & 3 & 4 \\
\hline \multirow[t]{2}{*}{ Numbu } & $9,56(91,33) \mathrm{a}$ & $9,62(92,67) \mathrm{a}$ & $9,51(90,54) \mathrm{a}$ & $8,75(76,67) b$ \\
\hline & A & A & A & $\mathrm{B}$ \\
\hline \multirow[t]{2}{*}{ Keller } & $9,41(88,67)$ a & $8,82(78,00) \mathrm{b}$ & $9,45(89,33)$ a & $9,20(84,67) \mathrm{a}$ \\
\hline & A & B & A & A \\
\hline \multirow[t]{2}{*}{ Wray } & $9,52(90,67) \mathrm{a}$ & $9,62(92,67) \mathrm{a}$ & $9,73(94,67) \mathrm{a}$ & $9,41(88,67)$ a \\
\hline & A & A & A & $\mathrm{A}$ \\
\hline Nilai BNT 0,01 & $\mathrm{G}=0,29$ & $P=0,33$ & & \\
\hline Keterangan : $\mathrm{G}=$ & $\begin{array}{l}\text { rietas, } \mathrm{P}=\text { populasi } \\
\text { rdasarkan uji BNT } \\
\text { tuk perbandingan } \\
\text { nsformasi }\end{array}$ & $\begin{array}{l}\text { ua nilai tengah yang } \\
\text { da g } 0,01 \text {. Huruf ke } \\
\text { am kolom. Angka d }\end{array}$ & $\begin{array}{l}\text { uti dengan huruf ya } \\
\text { ntuk perbandingan } \\
\text { kurung adalah ni }\end{array}$ & $\begin{array}{l}\text { na tidak berbeda nyata } \\
\text { baris dan huruf besar } \\
\text { sebelum }\end{array}$ \\
\hline
\end{tabular}

Tabel 6. Interaksi varietas dan populasi pada variabel pengamatan benih mati pada pengusangan cepat menggunakan etanol $8 \%$

\begin{tabular}{lcccc}
\hline \multirow{2}{*}{ Varietas Sorgum } & \multicolumn{4}{c}{ Jumlah tanam per lubang } \\
\cline { 2 - 5 } & 1 & 2 & 3 & 4 \\
\hline Numbu & $7,33 \mathrm{a}$ & $6,67 \mathrm{a}$ & $6,00 \mathrm{a}$ & $16,67 \mathrm{~b}$ \\
& $\mathrm{~A}$ & $\mathrm{AB}$ & $\mathrm{A}$ & $\mathrm{B}$ \\
Keller & $10,00 \mathrm{ab}$ & $20,67 \mathrm{~b}$ & $8,00 \mathrm{a}$ & $11,33 \mathrm{ab}$ \\
& $\mathrm{A}$ & $\mathrm{B}$ & $\mathrm{A}$ & $\mathrm{AB}$ \\
Wray & $8,67 \mathrm{ab}$ & $5,33 \mathrm{ab}$ & $4,00 \mathrm{a}$ & $\mathrm{A}$ \\
& $\mathrm{A}$ & $\mathrm{A}$ & $\mathrm{A}$ & $\mathrm{A}$ \\
\hline
\end{tabular}

Nilai BNT 0,01 $\quad \mathrm{G}=4,95 \quad \mathrm{P}=5,71$

Keterangan : $\mathrm{G}=$ varietas, $\mathrm{P}=$ populasi. Dua nilai tengah yang diikuti dengan huruf yang sama tidak berbeda nyata berdasarkan uji BNT pada g 0,01. Huruf kecil untuk perbandingan dalam baris dan huruf besar untuk perbandingan dalam kolom.

Tabel 7. Interaksi varietas dan populasi pada variabel pengamatan kecambah normal lemah pada pengusangan cepat menggunakan etanol $8 \%$

\begin{tabular}{lcccc}
\hline \multirow{2}{*}{ Varietas Sorgum } & \multicolumn{4}{c}{ Jumlah tanam per lubang } \\
\cline { 2 - 5 } Numbu & 1 & 2 & 3 & 4 \\
& $2,19 \mathrm{a}$ & $2,55 \mathrm{ab}$ & $2,64 \mathrm{ab}$ & $3,60 \mathrm{~b}$ \\
Keller & $\mathrm{A}$ & $\mathrm{A}$ & $\mathrm{A}$ & $\mathrm{AB}$ \\
& $4,71 \mathrm{~b}$ & $3,37 \mathrm{a}$ & $4,73 \mathrm{~b}$ & $4,42 \mathrm{ab}$ \\
Wray & $\mathrm{B}$ & $\mathrm{AB}$ & $\mathrm{B}$ & $3,48 \mathrm{a}$ \\
& $5,32 \mathrm{~b}$ & $4,59 \mathrm{~b}$ & $4,98 \mathrm{~b}$ & $\mathrm{~A}$ \\
\hline Nilai BNT 0,01 & $\mathrm{~B}$ & $\mathrm{~B}$ & $\mathrm{AB}$ &
\end{tabular}

Keterangan : $\mathrm{G}=$ varietas, $\mathrm{P}=$ populasi. Dua nilai tengah yang diikuti dengan huruf yang sama tidak berbeda nyata berdasarkan uji BNT pada g 0,01. Huruf kecil untuk perbandingan dalam baris dan huruf besar untuk perbandingan dalam kolom.

Pada variabel kecambah normal lemah, dan panjang kecambah normal, interaksi menunjukan perbedaan dibandingkan variabel pengamatan sebelumnya. Persentase kecambah normal lemah terendah ditunjukan oleh benih varietas Numbu pada semua populasi tanam dan persentase tertinggi ditunjukan pada varietas Wray pada seluruh populasi tanam baik 1,2,3 maupun 4 tanaman/lubang. Hal ini dapat disimpulkan bahwa varietas Numbu memiliki vigor tebaik pada populasi 1, 2, dan 3 tanaman 
Lidya Purnamasari dkk: Pengaruh Jumlah Tanaman Per Lubang Terhadap Vigor Benih Tiga Varietas Sorgum...

per lubang dibandingkan varietas Keller dan Wray namun pada pada benih yang ditanam pada populasi 4 tanaman per lubang, benih sorgum varietas Numbu menunjukan penurunan hasil yang signifikan sehingga varietas Numbu tidak mampu ditanam pada populasi 4 tanaman/lubang.

Tabel 8. Interaksi varietas dan populasi pada variabel pengamatan panjang kecambah normal pada pengusangan cepat menggunakan etanol $8 \%$

\begin{tabular}{lcccc} 
Varietas Sorgum & \multicolumn{4}{c}{ Jumlah tanam per lubang } \\
\cline { 2 - 5 } & 1 & 2 & 3 & 4 \\
\hline Numbu & $29,74(\mathrm{a})$ & $28,20 \mathrm{a}$ & $25,26 \mathrm{ab}$ & $24,28 \mathrm{~b}$ \\
& $\mathrm{~A}$ & $\mathrm{~A}$ & $\mathrm{~A}$ & $\mathrm{~A}$ \\
Keller & $22,27(\mathrm{a})$ & $25,82 \mathrm{a}$ & $22,65 \mathrm{a}$ & $22,02 \mathrm{a}$ \\
& $\mathrm{C}$ & $\mathrm{B}$ & $\mathrm{AB}$ & $\mathrm{B}$ \\
Wray & $24,72(\mathrm{a})$ & $21,99 \mathrm{ab}$ & $20,66 \mathrm{~b}$ & $19,22 \mathrm{c}$ \\
& $\mathrm{B}$ & $\mathrm{C}$ & $\mathrm{B}$ & $\mathrm{C}$ \\
\hline Nilai BNT 0,01 & $\mathrm{G}=2,19$ & $\mathrm{P}=2,53$ & &
\end{tabular}

\footnotetext{
Keterangan : $\mathrm{G}=$ varietas, $\mathrm{P}=$ populasi. Dua nilai tengah yang diikuti dengan huruf yang sama tidak berbeda nyata berdasarkan uji BNT pada g 0,01 . Huruf kecil untuk perbandingan dalam baris dan huruf besar untuk perbandingan dalam kolom.
}

Dari keseluruhan interaksi diatas, genotipe menunjukan respon jika dikombinasikan dengan kerapatan yang berbeda. Untuk interaksi antara varietas dan populasi didominansi oleh varietas Numbu dengan kerapatan 1, 2, dan 3 tanaman/lubang. Hal ini menunjukan bahwa varietas Numbu dengan kerapatan tersebut lebih baik apabila dibandingkan dengan genotipe dan kerapatan lainnya dalam semua variabel pengamatan. Namun semakin tinggi kerapatan, Numbu menunjukan penurunan mutu yang sangat signifikan dibandingkan varietas Keller dan Wray. Prasetiyowati (2005) dalam Alsabah (2014) menyatakan bahwa pada tingkat kepadatan tanaman yang sama setiap varietas dapat memberikan respon yang berbeda-beda pula terhadap lingkungan.

Persentase kecambah normal total memiliki keterkaitan yang positif terhadap kecepatan perkecambahan, benih mati dan panjang kecambah normal yang dipengaruhi oleh jumlah tanaman per lubang yang berbeda dan varietas yang berbeda.

Menurut Sadjad (1993) benih bermutu dapat dihasilkan apabila seluruh rentetan prosedur produksi benih yang berawal dari persiapan lahan yang menjamin bebas dari kontaminasi genetik, pengadaan benih sumber yang menjamin mutunya, sampai dengan pengolahan benih setelah panen dan penanganannya harus dilaksanakan secara sempurna. Semua permasalahan mencakup dalam ilmu dan teknologi benih penyelesaian akhirnya dipengaruhi oleh faktor-faktor lingkungan dan benihnya sendiri. pertumbuhan tanaman induk yang baik merupakan syarat yang mantap sewaktu tersebut. Selanjutnya penyakit dan hama, kekurangan air serta kekurangan makanan, baik pada tanaman induk sewaktu pertumbuhan dan perkembangannya atau pada waktu pematangan fisik benih tersebut, faktor yang demikian berpengaruh terhadap tingginya viabilitas dan vigor benih (Kartasapoetra, 2003).

\section{KESIMPULAN}

Berdasarkan hasil penelitian dan pembahasan dapat diambil kesimpulan yaitu varietas Keller dan Wray dapat ditanam hingga 4 tanaman/lubang sedangkan tanaman sorgum varietas Numbu bisa ditanam sampai dengan 3 tanaman/lubang karena pada populasi 4 tanaman/lubang benih varietas ini sudah menunjukkan penurunan vigornya. 
Jurnal Penelitian Pertanian Terapan

\section{DAFTAR PUSTAKA}

Alsabah, R. 2014. Akumulasi Bahan Kering Beberapa Varietas Jagung (Zea mays L.) yang Ditumpangsarikan dengan Ubikayu (Manihot esculenta Crantz). Skripsi. Fakultas Pertanian Universitas Lampung. Bandar Lampung.

Badan Pusat Statistik. 2010. Laju Pertumbuhan Penduduk. Diakses dari www.sp2010.bps.go.id pada tanggal 01 November 2013

Effendi, S. 1997. Bercocok Tanam jagung. CV Yasaguna, Jakarta. 95 hlm

Farnhamm, D.E. 2001. Row Spacing, Plant Density, and Hybrid Effects on Corn Grain Yield and Moisture. J. Agron. 93: 1049-1053

Gani, J. A. 2000. Kedelai Varietas Unggul. Lembar Informasi Pertanian (Liptan),Instalasi Penelitian dan Pengkajian Teknologi Pertanian, Mataram.

Gardner, F.P. Pearce, R.B dan Mitchel, R. L. (1991). Physiology ofof Crop Plant (Fisiologi Tanaman Budidaya, alih Bahasa oleh HerawatiSusilo). Jakarta : University of Indonesia Press

Irfan, M. 1999. Respon Tanaman Jagung (Zea mays L.) terhadap Pengolahan Tanah dan Kerapatan Tanam pada Tanah Andisol dan Ultisol. Pasca Sarjana Universitas Sumatera Utara, Medan. Hal 7, 13.

Justice, O.L,. dan L.N. Bass. 2002. Prinsip dan Praktek Penyimpanan Benih. PT Raja Grafindo Persada . Jakarta. $446 \mathrm{hlm}$.

Kartasapoetra, A.G. 2003. Teknologi benih : Pengolaan Benih dan tuntutan Praktikum. PT Rineka Cipta. Jakarta. $188 \mathrm{hlm}$

Mugnisjah, W,Q., A. Setiawan, Suwarto, dan C. Santiwa. 1994. Panduan Praktikum dan Penelitian Bidang Ilmu dan Teknologi Benih. PT. Grafindo Persada. Jakarta. 204 hlm

Nurfaidah, 2012. Budidaya Sorgum .Masagena Press. Makasar. 88 hlm.

Pian, Z. A. 1981. Pengaruh Uap Etil Alkohol Terhadap Viabilitas Benih Jagung (Zea mays L.) dan Pemanfaatan untuk Menduga Daya Simpan. Disertasi. Institut Pertanian Bogor. 222 hlm

Pramono, E. 2009. Daya Simpan Dugaan 90\% (DSD-90) dari Intensitas Pengusangan Cepat Kimiawi dengan Uap Etanol (IPCKU) Pada Benih Kacang Tanah (Arachis hypogea L.). Hasil Penelitian dan Pengabdian kepada Masyarakat. Unila. $7 \mathrm{hlm}$

Pramono, E. 2009. Penuntun Praktikum Dasar-dasar Teknologi Benih. Jurusan Budidaya Pertanian, Unila $26 \mathrm{Hlm}$.

Rambitan, V. M. M. 2003. Pertumbuhan dan hasil empat kultivar jagung semi (baby corn) dengan berbagai populasi tanaman pada Inceptisols Jatinangor. Jurnal Agroland 11: 1t-t7

Sadjad S. 1993. Dari Benih kepada Benih. PT. Grasindo. Jakarta

Sadjad S. 1994. Kuantifikasi Metabolisme Benih. PT. Gramedia Widiasarana Indonesia. Jakarta. 
Lidya Purnamasari dkk: Pengaruh Jumlah Tanaman Per Lubang Terhadap Vigor Benih Tiga Varietas Sorgum...

Sadjad, S.,E. Murniati, dan S. Ilyas. 1999. Parameter Pengujian Vigor Benih. PT Grasindo Bekerja sama dengan PT Sang Hyang Seri. Jakarta. $286 \mathrm{hlm}$

Sadjad, Sjamsoeoed, 1993. Kuantitas Metabolisme Benih. Rasindo. Bogor. 145 hlm.

Saenong, S. 1986. Pengaruh Vigor Benih Terhadap Vigor Tanaman di Lapangan dan Daya Simpan Benih Jagung Tesis. Institut Pertanian Bogor. 200 hlm

Salomao, A. N. 2002. Tropical Seeds Species Responces to Liquid Nitrogen Exposu- re. Braz J. Plant Physiol. $14: 133-138 \mathrm{hlm}$

Sirappa, M. P. 2003. Prospek Pengembangan Sorgum di Indonesia Sebagai Komoditas Alternatif untuk Pangan, Pakan dan Industri. Jurnal Litbang Pertanian.

Sofyadi, Edy. 2011. Aspek Budidaya, Prospek, Kendala, dan Solusi Pengembangan Sorgum di Indonesia

Sugito,Yogi.1999.EkologiTanaman.Fak.Pertanian.Universitas.Brawijaya.Malang.

Sutopo, Lita. 2002. Teknologi Benih. Universitas Brawijaya. Raja Grafindo Persada Jakarta

Usman Made, 2010. Respons Berbagai Populasi Tanaman Jagung Manis (Zea Mays Saccharata Sturt.)

Terhadap Pemberian Pupuk Urea Balai Penelitian Universitas Tadulako, Palu. 